\title{
Meninjau Kemampuan Penalaran Matematis Siswa SMP melalui Wawancara Berbasis Tugas Geometri
}

\author{
Nurfadilah Siregar \\ Mahasiswa Pendidikan Matematika SPs UPI \\ e-mail: nfsiregar@gmail.com
}

\begin{abstract}
ABSTRAK
Studi awal atau biasa disebut dengan pilot study merupakan studi pendahuluan yang dilakukan oleh kebanyakan peneliti sebagai suatu hal yang penting dalam proyek penelitian selanjutnya. Pada tulisan ini, penulis memaparkan hasil wawancara yang dilakukan dengan dua orang siswa kelas VIII pada salah satu sekolah menengah pertama di Kabupaten Bandung Barat terkait dengan menggali penalaran matematis siswa SMP. Wawancara dilakukan dengan menggunakan pedoman wawancara berbasis tugas geometri. Diperoleh hasil bahwa penalaran matematis kedua siswa tersebut terkait penyelesaian tugas geometri masih rendah. Siswa lebih cenderung menyelesaikan tugas secara langsung tanpa mengetahui alasan mereka menjawab tugas geometri tersebut.
\end{abstract}

Kata kunci: wawancara berbasis tugas, geometri, penalaran matematis

ABSTRACT

Preliminary study or commonly called the pilot study is a study conducted by most researchers as an important issue in future research projects. In this paper, the author present results of interviews conducted with two students in eighth grade at one of junior high school in West Bandung regency about digging their mathematical reasoning. Interviews were conducted by using a task-based geometry. The results indicate that mathematical reasoning of the students' related to the completion of geometry task still low. Students more likely to complete tasks directly without knowing the reason they answered the geometry tasks.

Keywords: task-based interview, geometry, mathematical reasoning

\section{PENDAHULUAN}

Secara umum studi awal atau biasa disebut dengan pilot study merupakan studi pendahuluan yang dilakukan oleh kebanyakan peneliti sebagai suatu hal yang penting dalam proyek penelitian selanjutnya. Pada tulisan ini, penulis memaparkan hasil studi awal yang telah penulis lakukan berupa transkrip wawancara yang dilakukan dengan dua orang siswa kelas VIII pada salah satu sekolah menengah pertama di Kabupaten Bandung Barat. Adapun maksud dilakukannya studi awal ini adalah untuk meninjau kemampuan penalaran matematis siswa sekolah menengah pertama terhadap konsep geometri.

Wawancara dilakukan dengan cara terlebih dahulu memperhatikan jawaban siswa terhadap tugas yang diberikan. Dari studi terdahulu yang dilakukan oleh Goldin (1998) mengenai wawancara berbasis tugas ini penting, salah satunya untuk memperoleh informasi mengenai metode pengajaran yang sesuai untuk mengembangkan kemampuan matematis siswa.

Pada dasarnya sifat ilmiah wawancara berbasis tugas ini digunakan pada studi jangka panjang yang membutuhkan suatu eksplorasi yang mendalam, sedangkan dalam tulisan ini hanya berupa pilot study. Disadarai bahwa transkrip wawancara yang diberikan pada siswa belum merupakan hasil akhir karena masih terdapat banyak kekurangan dalam menyusun wawancara terstruktur, baik dari segi validitas dan reliabilitas. Namun demikian, tidaklah menjadi suatu alasan yang 
mendasar bahwa dalam menyusun tulisan ini tidak dibenarkan studi awal dengan menggunakan wawancara berbasis tugas.

\section{METODE}

Tulisan ini berisi ulasan mengenai transkrip wawancara antara penulis dengan dua orang siswa kelas VIII di salah satu sekolah menengah pertama di Kabupaten Bandung Barat. Pelaksanaan wawancara pada tanggal 16 Mei 2014 di hari Jum'at setelah siswa tersebut melakukan kegiatan inti di kelasnya (pada pukul 13.30 - 14.30 WIB, pada jam tersebut kegiatan di sekolah berupa ekstrakurikuler). Kepada kedua orang siswa tersebut, penulis sebelumnya memperkenalkan diri sebagai teman dari guru mereka dan ingin mengajukan beberapa pertanyaan mengenai konsep geometri yang pernah dan masih mereka pelajari sampai saat ini. Pemilihan kedua siswa mempertimbangkan kemampuan yang berbeda, yakni baik dan sedang berdasarkan saran dari guru kelas. Diawali dengan perkenalan diri masing-masing siswa, penulis memberikan lembaran tugas geometri yang akan dikerjakan secara individu. Berikut ini tugas geometri yang penulis berikan:

1. Macam-macam bentuk geometri datar. Temukan beberapa bentuk geometri dari gambar berikut. Daftarkan namanya sesuai dengan titik yang ada. Berikan alasan pada setiap jawaban kamu.

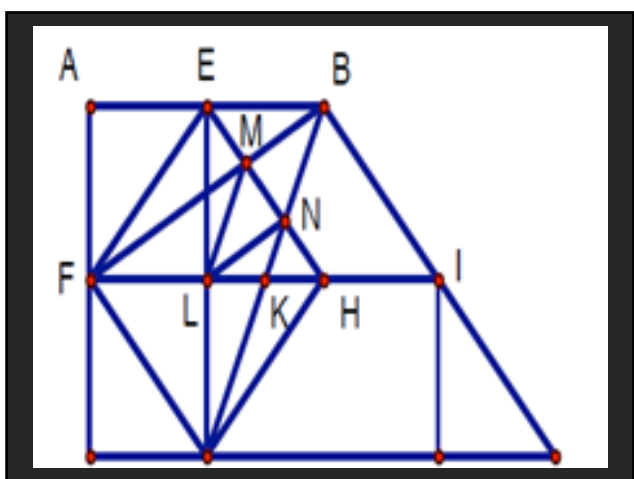

Gambar 1. Beberapa Bentuk Geometri
2. Sudut dalam dan luar segitiga.

Benarkah jumlah dari sudut $\mathrm{ABC}$ dan sudut BAC sama dengan sudut BCD? Berikan alasan dari pernyataan yang kamu berikan.

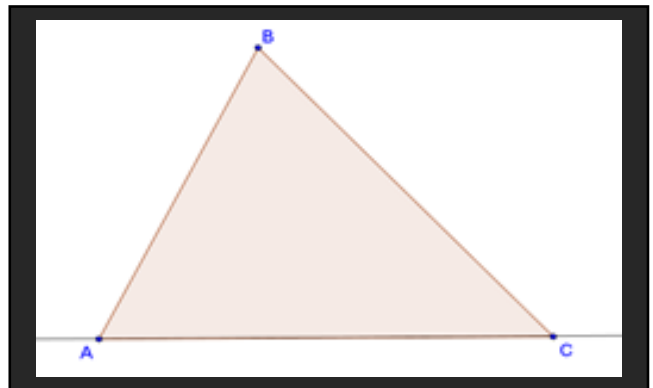

Gambar 2. Beberapa Segitiga ABC

3. Tentukanlah nilai kebenaran dari pernyataan berikut ini dan jelaskan pendapat kamu.

a. Semua sifat yang ada pada persegi panjang dimiliki oleh semua persegi.

b. Jika ukuran $\angle \mathrm{A}+$ ukuran $\angle \mathrm{B}=$ $100^{\circ}$ dan ukuran $\angle \mathrm{B}=40^{\circ}$ maka segitiga yang terbentuk adalah segitiga lancip.

c. Pada segitiga XYZ, diketahui bahwa ukuran $\angle \mathrm{X}=$ ukuran $\angle \mathrm{Y}=$ ukuran $\angle$ Z. Dengan demikian, panjang sisi $\quad \overline{\mathrm{XY}} \neq$ panjang sisi $\overline{\mathrm{YZ}} \neq$ panjang sisi $\overline{X Z}$.

Wawancara dilakukan setelah siswa tersebut menyelesaikan satu buah tugas. Adapun format wawancara disajikan dalam beberapa proses seperti diadopsi dari Luka (2013) berikut: 
Tabel 3. Format Wawancara Siswa

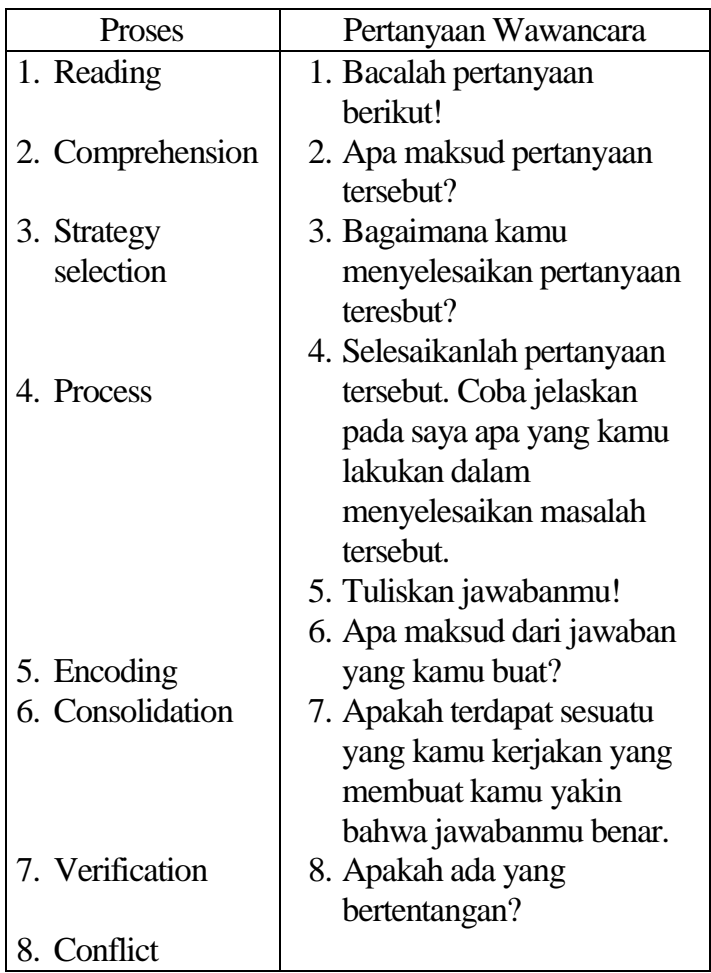

\section{HASIL DAN PEMBAHASAN}

Berikut ini adalah petikan wawancara dengan kedua orang siswa kelas VIII. Siswa yang memiliki kemampuan sedang dikodekan dengan $\mathrm{S} 1$, siswa dengan kemampuan baik dikodekan dengan S2, sedangkan penulis sendiri sebagai pewawancara dikodekan dengan $\mathrm{P}$.

1. Macam-macam bentuk geometri datar

$\mathrm{P}$ : Sudah selesai mengerjakan pertanyaan pertama?

S1 dan S2: Sudah bu.

$\mathrm{P} \quad$ : Kalau sudah dibaca, apa maksud pertanyaannya?

S1 : Bentuk geometri ya, contohnya kotakkan.

S2 : Persegi, bukan kotak

S1 : Oh iya.

$\mathrm{P} \quad$ : Selain itu ada apa lagi?

S1 dan S2: Berarti ini (Sambil menunjuk gambar pada tugas pertama) dituliskan nama-nama bangun geometrinya ya?
P : Apa perintah soalnya? Temukan beberapa bentuk geometri, daftarkan namanya sesuai dengan titik yang ada.

S2 : Ini bentuknya ada belah ketupat, segitiga sembarang.

S1 : Iya, mengerti. Jadi ini bentuknya ada belah ketupat atau jajaran genjang ya?

$\mathrm{P} \quad$ : Kenapa belah ketupat? Jajaran genjang yang mana?

S1 : Eh, ini sama ga sih? Hampir sama ya. (Sambil menunjuk FGHE dan BMLN).

$\mathrm{P} \quad$ : Coba gambarkan belah ketupat dan jajaran genjang! Apa bedanya?

S1 :Hhmm... Ga tau

S2 : Diagonalnya kan ya, tegak lurus kalau yang ini (FGHE), 90 .

$\mathrm{P} \quad$ : Selain itu, bentuk geometrinya apa lagi?

S1 : Trapesium sembarang.

S2 : Trapesium sembarang? Ga ada kali.

$\mathrm{P} \quad$ : Yang dimaksud trapesium itu bagaimana?

S1 dan S2: Ini (Sambil meunjukkan hasil gambarnya pada geobord).

$\mathrm{P} \quad$ : Jadi, ada tidak trapesium sembarang?

S1 dan S2: Ga tau bu.

$\mathrm{P} \quad$ : Apa syaratnya dikatakan trapesium?

S2 : Kalau ada sepasang yang sejajar ya bu.

$\mathrm{P} \quad$ : Sejajar itu yang bagaimana?

S2 : Begini bu (Sambil mengangkat kedua tangannya, lalu menyatukannya diujung jari).

$\mathrm{P} \quad$ : Kalau begitu nanti akan berpotongan, sedangkan sejajar artinya tidak akan berpotongan atau bertemu disatu titik.

S2 : Eh iya, jadi gimana bu? 
$\mathrm{P} \quad$ : Apa mungkin seperti ini?

(Sambil mengangkat tangan atas dan bawah, sejajar).

S1 dan S2: Oh iya.

$\mathrm{P} \quad$ : Kalau segitiga ada bentukbentuknya tidak?

S1 dan S2: Ada bu, segitiga sama kaki, sembarang, siku-siku, dan sama sisi.

P : Udah didaftarkan jawabannya?

S1 dan S2: Sudah bu, semuanya ya?

$\mathrm{P} \quad$ : Terserah kamu, seberapa banyak, kalau banyak juga tidak apa, minimal 1. Bagaimana dengan bentuk persegi dan persegi panjang?

S1 dan S2: Sudah juga bu, semuanya dituliskan ya bu.

$\mathrm{P} \quad$ : Jadi udah semua bentuk geometri dituliskan?

S1 dan S2: Iya bu, sudah semua.

$\mathrm{P} \quad$ : Jadi yang masuk segi empat apa saja? Bagaimana dengan segi tiga?

S1 dan S2: (Sambil menunjukkan jawabannya masing-masing).

$\mathrm{P} \quad$ : Bisakah kamu membuat

diagram yang menunjukkan kalau itu

(Sambil menunjukkan gambar pada tugas pertama) termasuk segi empat atau segi tiga?

S1 dan S2: Udah gini aja deh bu. Ga usah dikelompokkan lagi.

$\mathrm{P} \quad$ : Baiklah.

2. Sudut dalam dan luar segitiga.

$\mathrm{P} \quad$ : Sekarang tugas yang kedua, sudah dikerjakan?

S1 : Ini maksudnya apa bu? Eh, sudah tau bu.

$\mathrm{P} \quad$ : Coba baca pertanyaannya, maksudnya apa kira-kira?

S2 : Begini bu, ini kan sudut sejajar. Eh, sudut pelurus ya (Sambil menunjuk gambar pada tugas kedua, membuat setengah lingkaran). Ini kan sudut dalam segitiga $180^{\circ}$ (Sambil menunjuk sudut dalam segitiga $\mathrm{ABC}$ ), benarkan?

S1 : Haduh, ga ngerti. Ga suka yang begini bu.

$\mathrm{P} \quad$ : Kenapa? Coba yang mana yang tidak mengerti?

S1 : Udah kan bu, gini ajalah, sudutnya $180^{\circ}$.

P : Eh, belum, terus diapakan?

S2 : Ini sudut apa bu namanya?

(Sambil menunjuk sudut C)

$\mathrm{P}$ : Coba buat masing-masing sudut $\mathrm{C} 1$ dan $\mathrm{C} 2$ (Buat berbeda pada masing-masing sudut dalam dan luar). S2 : Oh, ini jadi sudut $\mathrm{C} 1$, yang ini jadinya sudut $\mathrm{C} 2$. Kalau mau bilang yang ini (Sambil menunjuk sudut C) diapain gitu ya. Saya menjawabnya dijelaskan aja ya bu, tidak usah ditulis, diomongin aja, kalau dituliskan susah.

S1 : Saya sudah bu, begini aja. $\mathrm{Ga}$ tau lagi mau diapain.

P : Coba tuliskan sepemahaman kamu saja. Tidak masalah kalau benar ataupun salah. Ibu hanya mau melihat kemampuan kamu dalam menuliskan bukti, kalau memang tidak bisa, tidak mengapa.

S1 dan S2: Baik bu (Sambil menuliskan jawaban pada lembar yang tersedia).

3. Menentukan kebenaran pernyataan.

a. P : Bagaimana dengan pernyataan bagian (a), benar atau salah?

S2 : Ini dibuat perbedaannya ya bu?

S1 : Sudah bu, begini kan bu (Sambil menggambar persegi panjang). Karna kalau persegi panjang dibagi dua atau dibagi berapa jadinya persegi. Jadi jawabnya benar. 
$\mathrm{P} \quad$ : Apa sifat yang dimiliki persegi panjang dan persegi? Ada yang tau?

S1 dan S2 : Apa ya bu.

S2 : (Membuat perbedaan antara persegi panjang dan persegi), kalau begitu persegi ini bagian dari persegi panjang. Benar jawabannya, karena apa ya.

$\mathrm{P}$ : Bagaimana dengan ukuran sudut dan sisinya?

S2 : Sudutnya sama bu, $90^{\circ}$. Kalau sisinya, persegi panjang kedua sisinya sejajar, persegi sisinya sama panjang.

P : Iya, kalau memang seperti itu silahkan tuliskan jawaban kamu dilembar yang disediakan.

b. P : Sekarang masuk pernyataan pada bagian (b). Mengerti maksud pernyataan tersebut?

S2 : Ini maksudnya ukuran sudut A $60^{\circ}$ ya kan bu.

$\mathrm{P} \quad$ : Kenapa begitu? Taunya darimana?

S2 : Karena $100^{\circ}-40^{\circ}=60^{\circ}$

S1 : Oh, terus bagaimana?

S2 : Sudut $C$ nya diamana ya?

$\mathrm{P}$ : Coba digambarkan segitiga yang dimaksud.

S2 : (Menggambarkan segitiga dengan masing-masing sudutnya). Oh, jadi sudut $\mathrm{C}$ nya disini (Sambil menunjuk sudut yang belum memiliki ukuran.

S1 : Tidak ada sudut $\mathrm{C}$ nya bu. Adanya sudut B1 dan B2 ya bu?

P : Jadi kalau udah tau masing-masing ukuran sudutnya, selanjutnya bagaimana?

S2 : Namanya segitiga apa ya, sudutnya kurang dari $90^{\circ}$.

$\mathrm{P} \quad$ : Apa namanya sudut yang kurang dari $90^{\circ}$ ?

S1 dan S2 : Sudut lancip bu.
P : Nah, kalau semua sudut segitiganya kurang dari $90^{\circ}$, jadinya segitiga apa?

S2 : Oh iya, kan sudut segitiga jumlahnya $180^{\circ}$, ukuran sudut C nya berarti $80^{\circ}$, jadi namanya segitiga lancip. Benar ya bu.

S1 : Oh iya deh bu. Jadi benar ya, segitiga lancip karena sudut lancip kurang dari $90^{\circ}$.

$\mathrm{P} \quad$ : Kalau memang begitu, tulisan yang kamu buat bagaimana?

S1 dan S2 : Harus ditulis lagi ya bu?

$\mathrm{P}$ : Iya, mau dilihat pernyataan dari jawaban yang kamu buat. Jangan hanya jawab benar atau salah saja.

S1 dan S2 : Iya bu.

c. $\mathrm{P}$ : Bagaimana dengan pernyataan bagian (c)? Sudah ada yang menjawab? Apa jawabannya?

S1 : Ini maksudnya apa bu? Mungkin jawabannya benar bu. Iya kan bu?

S2 : Sepertinya jawabannya salah deh. Harusnya benar kan, segitiga sama sisi, sisinya sama panjang dan sudutnya sama besar. Jadi jawabannya salah ya kan bu.

$\mathrm{P} \quad$ : Harusnya bagaimana? Benar atau salah? Terserah kamu yang penting buat alasan kenapa kamu memberikan jawaban seperti itu.

S1 dan S2 : Baik bu (Sambil menuliskan jawaban ditempat yang disediakan).

Disela-sela kegiatan tersebut penulis juga mengajukan beberapa pertanyaan yang tidak terkait langsung dengan tugas yang diberikan. Berikut diantaranya: 
$\mathrm{P} \quad$ : Diantara mata pelajaran yang ada di sekolah, suka tidak dengan mata pelajaran Matematika?

S1 : Ga suka bu, saya lebih suka sama Bahasa Indonesia. Kalau S2 itu pasti suka bu.

S2 : Saya suka bu, daripada pelajaran yang menghafal, lebih suka yang menghitung bu. Tapi ga suka kalau membuktikan yang seperti tadi bu (Sambil mengingat tugas no.2).

$\mathrm{P} \quad$ : Kenapa begitu?

S1 : Ga suka aja bu, memang saya lemah kalau matematika bu.

S2 : Saya sering diajarin sama mama dan kakak di rumah bu. Jadi lebih paham lagi, kalau membuktikan gitu kan ga pernah bu.

$\mathrm{P} \quad$ : Itu tadi tugas yang dikerjakan mengenai Geometri, tau kan?

S1 dan S2 : Iya bu, tau.

S2 : Saya sukanya yang Aljabar bu.

S1 : Saya ga suka semuanya bu.

P : Oh, kalau di kelas pernah menggunakan alat bantu apa dalam belajar Geometri? Selain jangka, penggaris, dan busur? Komputer mungkin?

S1 dan S2 : Ga pernah bu, hanya menggunakan jangka, dan busur saja.

$\mathrm{P} \quad$ : Mungkin kalau pembelajarannya menggunakan alat bantu komputer bisa lebih menarik dan mudah dipahami. Jadi kalian juga bisa tambah suka dengan Matematika.

S1 dan S2 : Iya bu, mau dicoba kapankapan ya bu.

\section{Diskusi}

Pada studi awal ini, wawancara berbasis tugas digunakan untuk meninjau kemampuan siswa dalam bernalar terutama pada konsep geometri. Menurut Goldin (1998) salah satu tujuan dari wawancara berbasis tugas dalam pendidikan matematika adalah memungkinkan kita untuk mengkarakterisasi strategi anak, struktur pengetahuan, atau kompetensi yang mungkin efektif pada pengajaran, memahami proses perkembangan yang lebih baik, atau untuk mengeksplorasi perilaku pemecahan masalah. Dalam hal ini, kemampuan yang diamati adalah kemampuan penalaran matematis siswa.

Masih menurut Goldin (1998) pertanyaan yang diajukan dalam wawancara berbasis tugas sebaiknya bergantung pada teori yang dirujuk. Dengan demikian karena penulis mengambil pembahasan mengenai konsep geometri dan penalaran matematis, berikut ini penulis sajikan deskripsi singkat mengenai keduanya.

\section{Geometri}

Geometri sebagai salah satu bidang kajian dalam materi matematika sekolah memperoleh porsi yang besar untuk dipelajari oleh siswa di sekolah. Dari distribusi bidang kajian materi matematika sekolah menengah pertama diketahui bahwa $41 \%$ bidang kajian mengenai geometri dan pengukuran. Adapun materi geometri yang harus dikuasai siswa sesuai standar isi yang memuat standar kompetensi dan kompetensi dasar meliputi: hubungan antar garis, sudut (melukis sudut dan membagi sudut), segitiga (termasuk melukis segitiga) dan segi empat, teorema Pythagoras, lingkaran (garis singgung sekutu, lingkaran luar dan lingkaran dalam segitiga, dan melukisnya), kubus, balok, prisma, limas dan jaringjaringnya, kesebangunan dan kongruensi, tabung, kerucut, bola, serta menggunakannya dalam pemecahan masalah (Wardhani, 2008).

Dari sudut pandang psikologi, geometri merupakan penyajian abstraksi dari pengalaman visual dan spasial, misalnya bidang, pola, pengukuran dan pemetaan. Dari sudut pandang matematis, geometri menyediakan pendekatan- 
pendekatan untuk pemecahan masalah, misalnya gambar-gambar, diagram, sistem koordinat, vektor, dan transformasi (Abdussakir, 2009). National Concil of Teacher in Mathematic (NCTM) (Siregar, 2009) menyatakan bahwa secara umum kemampuan geometri yang harus dimiliki siswa adalah: (1) Mampu menganalisis karakter dan sifat dari bentuk geometri baik 2D atau 3D; dan mampu membangun argumen-argumen matematika mengenai hubungan geometri dengan yang lainnya; (2) Mampu menentukan kedudukan suatu titik dengan lebih spesifik dan gambaran hubungan spasial dengan menggunakan koordinat geometri serta menghubungkannya dengan sistem yang lain; (3) Aplikasi transformasi dan menggunakannya secara simetris untuk menganalisis situasi matematika; (4) Menggunakan visualisasi, penalaran spasial, dan model geometri untuk memecahkan permasalahan. Untuk itu NCTM (Mulyana, 2003) menganjurkan agar dalam pembelajaran geometri siswa dapat memvisualisasikan, menggambarkan, serta memperbandingkan bangun-bangun geometri dalam berbagai posisi, sehingga siswa dapat memahaminya.

\section{Penalaran Matematis}

Departemen Pendidikan Nasional (Shadiq, 2004) menyatakan bahwa "Materi matematika dan penalaran matematika merupakan dua hal yang tidak dapat dipisahkan, yaitu materi matematika dipahami melalui penalaran dan penalaran dipahami dan dilatihkan melalui belajar materi matematika". Hal ini menunjukkan bahwa penalaran merupakan unsur penting dalam belajar matematika bagi siswa. Penalaran adalah proses berpikir yang bertolak dari pengamatan yang menghasilkan sejumlah konsep dan pengertian (Wikipedia.com). Shurter dan Pierce (Dahlan, 2004) menjelaskan penalaran sebagai terjemahan dari reasoning yang didefinisikan sebagai proses pencapaian kesimpulan logis berdasarkan fakta dan sumber yang relevan. Senada dengan yang diungkapkan Keraf (Shadiq, 2004) bahwa penalaran atau reasoning sebagai proses berfikir yang berusaha menghubung-hubungkan fakta-fakta atau evidensi-evidensi yang diketahui menuju pada suatu kesimpulan.

Penalaran matematis (mathematical reasoning) diperlukan untuk menentukan apakah sebuah argumen matematika benar atau salah dan juga dipakai untuk membangun suatu argumen matematika. Menurut Mullis (Ulya, 2007) penalaran matematis mencakup kemampuan menemukan konjektur, analisis, evaluasi, generalisasi, koneksi, sintesis, pemecahan masalah tidak rutin, jastifikasi atau pembuktian, dan kemampuan komunikasi matematis.

Sumarmo (2010) mengungkapkan bahwa secara garis besar penalaran digolongkan dalam dua jenis yaitu penalaran induktif dan penalaran deduktif. Penalaran induktif adalah penarikan kesimpulan yang bersifat umum atau khusus berdasarkan data yang teramati, dimana nilai kebenaran dalam penalaran induktif dapat bersifat benar atau salah. Kegiatan yang tergolong penalaran induktif antara lain: (a) Transduktif: menarik kesimpulan dari satu kasus atau sifat khusus yang satu diterapkan pada yang kasus khusus lainnya; (b) Analogi: penarikan kesimpulan berdasarkan keseruapaan data atau proses; (c) Generalisasi: penarikan kesimpulan umum berdasarkan sejumlah data yang teramati; (d) Memperkirakan jawaban, solusi atau kecenderungan: interpolasi dan ekstrapolasi; (e) Memberi penjelasan terhadap model, fakta, sifat, hubungan, atau pola yang ada; (f) Menggunakan pola hubungan untuk menganalisis situasi, dan menyusun konjektur.

Sedangkan penalaran deduktif adalah penarikan kesimpulan berdasarkan aturan 
yang disepakati, dimana nilai kebenaran dalam penalaran deduktif mutlak benar atau salah dan tidak kedua-duanya. Kegiatan yang tergolong pada penalaran deduktif antara lain: (a) Melaksanakan perhitungan berdasarkan aturan atau rumus tertentu; (b) Menarik kesimpulan logis berdasarkan aturan inferensi, memeriksa validitas argumen, membuktikan, dan menyusun argumen yang valid; (c) Menyusun pembukltian langsung, pembuktian tak langsung dan pembuktian dengan induksi matematika.

Yumus (Siregar, 2009) mengungkapkan bahwa kemampuan reasoning adalah salah satu bagian dari kemampuan berfikir matematis, bagian dari komunikasi, metakognitif dan problem solving, juga terdiri dari kemampuan membuat keputusan dari berbagai situasi yang lebih spesifik dan lebih mendesak dengan mengkaitkannya dalam berbagai skema. Beliau membagi kemampuan penalaran matematis siswa atas empat bagian yaitu: (a) Level 1: Tidak memahami suatu proses penalaran; (b) Level 2: Memiliki pengetahuan berupa model, mengetahui fakta, sifat-sifat dan hubungannya tetapi tidak dapat menghasilkan argumen; (c) Level 3: Mampu melakukan penalaran dan membuat sebuah argumen yang lemah; (d) Level 4: Mampu menghasilkan argumen yang kuat untuk mendukung penalaran yang mereka hasilkan.

Siswa dikatakan mampu melakukan penalaran bila ia mampu menggunakan penalaran pada pola dan sifat, melakukan manipulasi matematika dalam membuat generalisasi, menyusun bukti, atau menjelaskan gagasan dan pernyataan matematika (Wardhani, 2008). Dalam kaitan itu pada penjelasan teknis pengisian rapor diuraikan bahwa indikator siswa memiliki kemampuan penalaran adalah: (a) Mengajukan dugaan; (b) Melakukan manipulasi matematika; (c) Menarik kesimpulan, menyusun bukti, memberikan alasan atau bukti terhadap kebenaran solusi; (d) Menarik kesimpulan dari pernyataan; (e) Memeriksa kesahihan suatu argumen; (f) Menemukan pola atau sifat dari gejala matematis untuk membuat generalisasi.

\section{PENUTUP}

Dari hasil wawancara yang penulis lakukan, ternyata masing-masing siswa memiliki kemampuan penalaran matematis yang berbeda dalam menyelesaikan tugas yang diberikan. Hal ini dapat dilihat dari jawaban dan petikan wawancara antara siswa yang memiliki kemampuan sedang (S1) dan siswa yang memiliki kemampuan baik (S2). Menurut penulis adanya kesenjangan antara kedua siswa tersebut dapat diminimalisir dengan melaksanakan pembelajaran geometri yang sesuai untuk semua kemampuan siswa.

Kemampuan siswa dalam bernalar sangat kurang dalam hal menyusun bukti, melakukan manipulasi matematika, dan menarik kesimpulan dari pernyataan. Siswa cenderung menjawab pertanyaan tanpa mengajukan dugaan terlebih dahulu, hal ini dimungkinkan karena selama ini siswa jarang memperoleh tugas yang sejenis. Seharusnya penalaran matematis siswa sejak awal dikembangkan dengan baik, sehingga diharapkan siswa dapat meyelesaikan permasalahan tidak hanya dalam konsep geometri yang terkait erat dengan penalaran tetapi juga pada materi lainnya. Tujuan pembelajaran geometri secara umum adalah agar siswa memperoleh rasa percaya diri mengenai kemampuan matematikanya, menjadi pemecah masalah yang baik, dapat berkomunikasi secara matematis, dan dapat bernalar secara matematis.

Akhirnya, dari hasil wawancara berdasarkan tugas geometri yang diberikan pada kedua siswa kelas VIII diperoleh beberapa catatan sebagai berikut:

1. Walaupun kedua siswa tersebut sudah pernah belajar mengenai materi segi 
empat dan segi tiga, akan tetapi mereka masih mengalami kesulitan dalam menentukan jenis segi empat ataupun segi tiga berdasarkan sifatsifatnya.

2. Kemungkinan besar guru jarang memberikan soal yang terkait dengan penalaran matematis terhadap konsep geometri.

3. Pembelajaran geometri yang dilakukan selama ini terkesan membosankan karena hanya menggunakan alat bantu "tradisional" berupa jangka, penggaris, dan busur.

4. Kemampuan siswa baik dan sedang pada saat menjawab tugas dan wawancara yang dilakukan kemungkinan memberikan pengaruh yang besar terhadap jawaban akhir siswa tersebut.

\section{Kesimpulan}

Studi awal yang dilakukan ini bukanlah menjadi akhir dari penelitian yang akan dilakukan penulis selanjutnya. Studi awal ini berfungsi sebagai langkah awal untuk menentukan apa yang harus dilakukan selanjutnya dalam meningkatkan kemampuan penalaran matematis siswa terhadap konsep geometri. Penyusunan bahan ajar dengan mempetimbangkan tingkat berpikir siswa dimungkinkan untuk penelitian selanjutnya, begitupun penggunaan alat bantu berupa media komputer dalam pembelajaran geometri maupun materi lainnya, sehingga siswa akan tertarik dengan mata pelajaran Matematika.

\section{DAFTAR PUSTAKA}

Abdussakir. (2009). Pembelajaran Geometri dan Teori Van Hiele. [Online]. Tersedia: http://abdussakir.wordpress.com. (26 Januari 2011).
Acquah, S. (2011). Pre-Service Teachers' Difficulties in Learning Geometric Transformations and Perception of Factors Inhibiting The Development of Their Mathematical Knowlede for Teaching: A Case Study of Two Colleges of Education. Thesis in University of Education, Winneba.

Alwasilah, C. (2003). Pokoknya Kualitatif: Dasar-dasar Merancang dan Melakukan Penelitian Kualitatif. Jakarta: Pustaka Jaya.

Atebe, H.U. (2008). Students' Van Hiele Levels of Geometric Thought And Conception In Plane Geometry: A Collective Case Study Of Nigeria And South Africa. Dissertation in Rhodes University.

Dahlan, J.A. (2004). Meningkatkan Kemampuan Penalaran dan Pemahaman Matematika Siswa Sekolah Menengah Lanjutan Tingkat Pertama Melalui Pendekatan Pembelajaran Open-Ended. Disertasi pada PPS UPI: Tidak diterbitkan.

Fraenkel, J.R., and Wallen, N.E. (1993). How to Design and Evaluate Research in Education, 2nd ed. New York: McGrawHill.

Forgasz, H.J., and Kaur, B. (1997). The Role of The Pilot Study in Mathematics Education Research. Association of Mathematics Educators: The Mathemmatics Educator, 2(2). 187-196.

Goldin, D. (1998). Observing Mathematical Problem Solving Throgh Task-Based Interview. In Teppo, A. Qualitative Research Methods in Mathematics Educationx. Reston: The National Council of Teachers of Mathematics Inc.

Kilic, H. (2009). The Effects Of Dynamic Geometry Software On Learning Geometry. CERME. 
Luka, M.T. (2013). Misconceptions And Errors In Algebra At Grade 11 Level: The Case Of Two Selected Secondary Schools In Petauke District. Thesis in The University Of Zambia.

Moleong, J L. (2009). Metodologi Penelitian Kualitatif. Bandung: PT Remaja Rosdakarya.

Marchius, I. (2012). Preservice Primary School Teachers' Elementary Geometry Knowledge. Acta Didactica Napocensia, vol.5 (2).

Mulyana, E. (2003). Masalah Ketidaktepatan Istilah dan Simbol dalam Geometri SLTP Kelas 1. Makalah. FPMIPA UPI.

Ruseffendi, E.T. (2005). Dasar-Dasar Penelitian Pendidikan \& Bidang NonEksakta Lainnya. Bandung: Tarsito.

Siregar, N. (2009). Studi Perbandingan Kemampuan Penalaran Matematik Siswa Madrasah Tsanawiyah Pada Kelas yang Belajar Geometri Berbantuan Geometer's Sketchpad Dengan Siswa yang Belajar Geometri Tanpa Geometer's Sketchpad. Tesis pada SPs UPI: Tidak diterbitkan.

Shadiq, F. (2004). Penalaran, Pemecahan Masalah dan Komunikasi Matematika. Diklat Instruktur/ Pengembangan Matematika SMP Jenjang Dasar. PPPG Matematika. Yogyakarta.

Sumarmo, U. (2010). Berfikir dan Disposisi Matematik: Apa, Mengapa, dan Bagaimana Dikembangkan pada Peserta Didik. FPMIPA UPI.

Ulya, N. (2007). Upaya Meningkatkan Kemampuan Penalaran dan Komunikasi Matematik Siswa Smp/Mts Melalui Pembelajaran Kooperatif Tipe Teams-GamesTournaments (TGT). Tesis pada SPs UPI: Tidak diterbitkan.
Wardhani, S. (2008). Analisis SI dan SKL Mata Pelajaran Matematika SMP/MTs untuk Optimalisasi Tujuan Mata Pelajaran Matematika. Pusat Pengembangan Dan Pemberdayaan Pendidik dan Tenaga Kependidikan Matematika. Yogyakarta

\section{RIWAYAT HIDUP PENULIS}

Nurfadilah Siregar, M.Pd. Lahir di kota

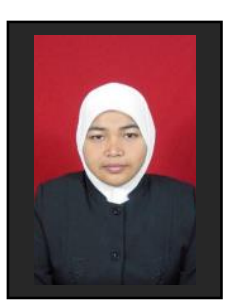

Medan pada tanggal 22 September 1986. Dosen luar biasa pada Universitas Widyatama, Bandung. Studi S1 pada bidang Pendidikan Matematika di UNIMED, Medan, lulus tahun 2008; S2 pada bidang Pendidikan Matematika di UPI, Bandung; dan S3 pada bidang Pendidikan Matematika di UPI, Bandung, sampai dengan saat ini. 